\title{
膀胱発癌に対するtryptophan代謝産物の役割に関する研究
}

\author{
第 II 編 FANFT（初発因子），1-tryptophan（促進因子） \\ によるマウス膀胱発癌実験
}

\begin{abstract}
東邦大学医学部泌尿器科学教室 松 島 正 浩
(主任: 安藤弘教授)
\end{abstract}
\section{THE ROLE OF L-TRYPTOPHAN'S PROMOTING FACTOR ON TUMORGENESIS \\ IN THE URINARY BLADDER}

2. URINARY BLADDER CARCINOGENICITYY OF FANFT (INIT'IATING

FACTOR) AND L-TRYPTOPHAN (PROMOTING FACTOR) IN MICE

\author{
Masahiro Matsushima \\ Department of Urology, School of Medicine, Toho University
}

(Director: K. Ando)

In order to investigate the role of 1-tryptophan's promoting factor on tumorgenesis in the urinary bladder, the following experiment was contemplated.

Sixty D-D strain female mice of 7-week-old were fed 0.1\% FANFT added CE-2 diet for 4-week duration. Thereafter, these mice were divided into two groups each comprising thirty mice $0.2 \% 1$ tryptophan added CE-2 diet for one group (group-1) and CE-2 diet for another (group-2) were fed for those mice in respective groups for another 56 weeks.

Results:

1) There were two cases of bladder tumor among the group-1 mice.

2) Both labeling index and hyperplastic index were statistically significant $(t=2.78, p<0.05)$ in group-1 mice when compared with group-2. From these results L-tryptophan's promoting factor on tumorgenesis in the urinary bladder seemed to be undeniable.

\section{緒言}

職業性膀胱癌患者が発癌物質の暴露後発癌に至るまで の潜伏期間は報告者により多少の差違はあるが，平均18 年の長期にわたる。そして外因性発癌物質である benzidine 2-naphthylamine などの芳香族アミンが初発因 子として重要な役割を演じていることは疑いもない事実 であり，一旦被暴された者はその後再び発癌物質に暴露 されなくても平均18年間の潜伏期間を経て発癌すること

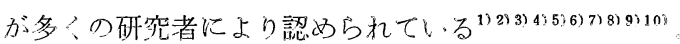
この発癌に至る 過程には, 種々の要因が作用するであ ろらが癌化を促進する一因子として尿中 tryptophan (以 下 try。と略す，Fig。1) 代謝産物が考光られることは 過去の膀胱発癌に関する研究結果から見て不自然ではな い。
Fig。1。<smiles></smiles>

1-Tryptophan

Fig. 2.<smiles></smiles>

N-[ 4-(5-nitro-2-furyl)-2-thiazolyl ] formamide

( FANFT ) 
今回, 著者は前述の膀胱発癌過程に批ける尿中 try.代 謝産物の促進因子としての役割を検討すべく， Ertürk ら ${ }^{11)}$ （1967）の報告した FANFT（Fig. 2) を初発因子 として投与した小動物発癌実験モデルを計画した。

\section{実験方法}

生後 7 週の D-D 系雌マウスを使用し, Fig. 3 亿示す ように飼育条件を異にする 4 群に分け実験した。飼育期 間は各群ともに60週である。

Fig. 3. Experimental method

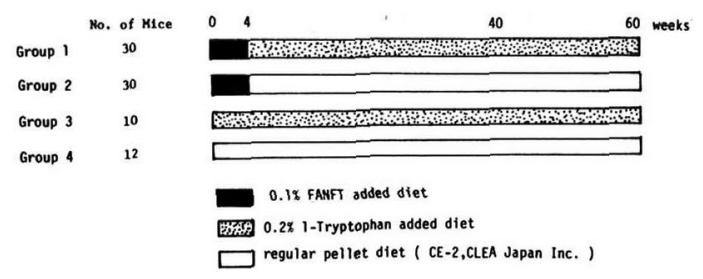

（1）実験動物群飼育条件

第 1 群 (30匹) : 0.1\% FANFT 添加 CE-2 粉末飼料 で 4 週間飼育後，0.2\% l-try. 添加 CE-2 固型飼料（日 本クレア K.K.) 飼育.

第 2 群 (30匹) : 0.1\% FANFT 添加 CE-2 粉末飼料 で 4 週間飼育後, CE-2固型飼料飼育.

第 3 群 (10匹)：CE-2 固型飼料で 4 週間飼育後, 0.2 $\%$ l-try 添加 CE-2 固型飼料飼育.

第 4 群 (12匹)：CE-2固型飼料単独で飼育 (対照群). 领料水は水道水で各群とも自由に摄取させた. 実験動 物は 1 ケージ 5 匹雑居飼育し, 体重測定は週 1 回行い, ケージ毎の平均值を調べ, かつ脱毛皮膚症状などの観察 より実験動物の健康状態を調查し, 実験期間中の室温は $20^{\circ} \mathrm{C} \sim 25$ に調整した。

（2）実験動物の屠殺処理法と ${ }^{3} \mathrm{H}$-thymidine による 膀胱粘膜の autoradiography 標本作製法.

実験動物の処理は, 飼育期間終了後体重測定し, $1 \mathrm{mc} /$ $\mathrm{ml}$ 含有の ${ }^{3} \mathrm{H}$-thymidine (specific activity $11.6 \mathrm{Ci} / \mathrm{mM}$ ) を生食水で10倍に希釈し, $1 \mu \mathrm{c} / \mathrm{g}$ (body weight) あて腹 腔内に注入. 1 時間後, エーテル麻醉下に頝動脈を切断 乙脱血屠殺して剖検し, 各主要藏器についての変化と腫 瘍形成の有無を肉眼的に観察した。ついで, 尿道側より 直接穿刺法で膀胼内にブアン氏液を注入し, 縦径が約 $1.0 \mathrm{~cm}$ になるよう膀胱を膨満せしめ固定した。各臓器 は10\%ホルマリン溶液で固定後, 厚さ $4 \sim 5 \mu$ のパラフ ィン切片を作製し光顕に供した. 膀胱は数日固定後正中
面で切半し光顕用切片を作製するとともに， autoradiography 標本作製は Sakura MR-M2 による dipping 法に 倣い, これを $4{ }^{\circ} \mathrm{C}$ 暗箱中に 4 週間露光し, レンドールで 現像, フジフィックスで定着し, Hematoxylin-Eosin で 後染色を行つた。

（3） autoradiography による膀胱粘膜細胞の labeling index 計算法

標本は原則的に光学顕微鏡 $(10 \times 100)$ で観察 し，1

Fig. 4. Labeled cells of bladder epithelium

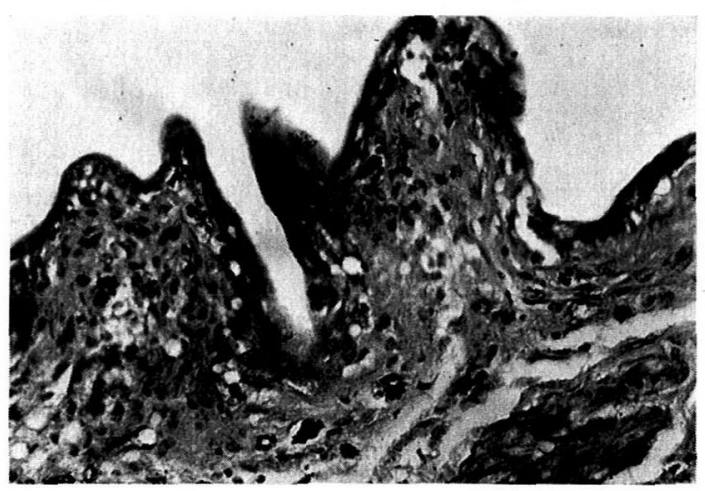

Tab. 1. Hyperplastic index (HPI) の計算方法

1）䐱肤粘膜首各部の細胞数之記号

\begin{tabular}{|c|c|c|c|}
\hline 観察部位 & a & b & c \\
\hline 膀 胱 頂 部 & $1-2$ & $3-4$ & $5-$ \\
\hline 尿管口附近 & $3-4$ & $5-6$ & 7- \\
\hline 内尿道口附近 & $5-6$ & $7-9$ & $9-$ \\
\hline
\end{tabular}

2) 点数 $(\mathrm{Ni})$ の入れかた

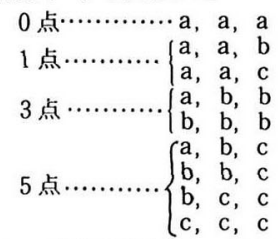

たとえば頂部附近か $1 \sim 2$ 層よりなり，尿管口 附近加 $8 \sim 9$ 層, 内尿道口附近加 $7 \sim 9$ 痛の標本 では a, c, b であるから 5 点となる.

3) 計算式

$$
\begin{aligned}
& \mathrm{HPI}:=\frac{20 \mathrm{~N}}{\mathrm{n}} \\
& \mathrm{N}: \text { 各動物の点数の和 }(\Sigma \mathrm{Ni}) \\
& \mathrm{n}: \text { 動物数 }
\end{aligned}
$$

4) 判定

50点以上 chemical induced

$30 \sim 50$ 点 indecisive

30点以下 inactive 
粘膜細胞に銀粒子 5 個以上認められるものを標識細胞と した．膀胱正中面に現われる膀胱粘膜細胞層のほぼ全体 を観察するため，約5,000個の細胞を数光，この中の標 識細胞数より labeling index を計算した。第 1 群の膀 胱粘膜上皮の標識細胞を Fig. 4に示した。

(4) hyperplastic index (HPI) の計算法

䧛胱粘膜の肥厚程度を数值で表わすために Clayson ら の方法を一部改良した宮川 ${ }^{12)}$ の测定方法 (Tab. 1) に準 じて HPI を計覮した。すなわち，膀脱頂暗，㽷管口附 近と内尿道口附近の 3 力所の膀胱粘膜の細胞数を a.b.c. つ記号に変え, これに基き各標本の点数定求め Tab. 1 の（3）の計算式より HPI を計算した。

\section{実験結果}

\section{(1) 各実験群の死亡率}

飼育60週目の各群の死亡率を Tab. 2 に示した.すな わち第 1 群 $30.0 \%$, 第 2 群 $46.6 \%$, 第 3 群 $10.0 \%$, 第 4 群 $8.3 \%$ であつた

（2）各垁験群の肉眼的剖検結果

剖検所見では各群とも膀胱を除き，心，循環系呼吸 器系, 朋, 腎, 消化器系, 性器などいずれの藏器にも腫 瘍の発生は確認できなかつた，膀脱内面の観察は標本作 製の必要上後日行われた。

Tab. 2. Mortality rate

\begin{tabular}{c|c|c|c|c}
\hline Groups & $\begin{array}{l}\text { No. of Mice } \\
\text { at Begining } \\
\text { of Experiment }\end{array}$ & $\begin{array}{l}\text { No. of Mice } \\
\text { Sacrificed at End } \\
\text { of Experiment }\end{array}$ & $\begin{array}{l}\text { No. of Mice } \\
\text { Died During } \\
\text { Experiment }\end{array}$ & $\begin{array}{l}\text { Mortality } \\
\text { Rate (\%) }\end{array}$ \\
\hline 1 & 30 & 21 & 9 & 30.0 \\
\hline 2 & 30 & 16 & 14 & 46.6 \\
\hline 3 & 10 & 9 & 1 & 10.0 \\
\hline 4 & 12 & 11 & 1 & 8.3 \\
\hline
\end{tabular}

Fig. 5 .

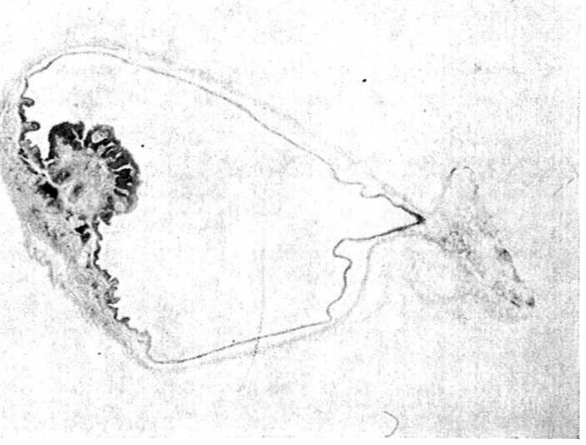

（3）各実験群の膀胱腫瘍発生率と labeling index

（イ）第 1 群; 実験飼育期間60週を経て生存したマウ 又数は当初30匹中 21 匹で， $ち 2$ 匹の膀胱内面（後壁） に乳頭状腫痬の発生（9.5\%）をみた（Fig. 5.6）。腫瘍

Fig. 6.

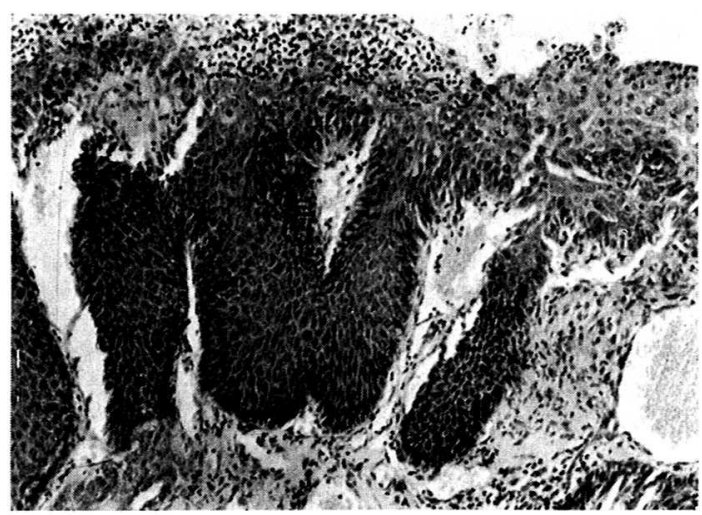

Tab. 3. Labeling of Bladder Epithelium by ${ }^{3} \mathrm{H}-$ Thymidine (Group-1)

\begin{tabular}{|c|c|c|c|}
\hline $\begin{array}{l}\text { Mouse } \\
\text { No. }\end{array}$ & $\begin{array}{l}\text { No. of cells } \\
\text { counted }\end{array}$ & $\begin{array}{l}\text { No. of } \\
\text { labeled cells }\end{array}$ & $\begin{array}{c}\text { Labeling index } \\
(\%)\end{array}$ \\
\hline 1 & 5014 & 55 & 1.10 \\
\hline 2 & 5008 & 15 & 0.30 \\
\hline 3 & 5000 & 6 & 0.12 \\
\hline 4 & 5003 & 80 & 1.60 \\
\hline 5 & 5000 & 7 & 0.14 \\
\hline 6 & 5005 & 11 & 0.22 \\
\hline 7 & 5005 & 10 & 0.20 \\
\hline 8 & 5096 & 43 & 0.85 \\
\hline 9 & 5000 & 3 & 0.06 \\
\hline 10 & 5000 & 8 & 0.16 \\
\hline 11 & 5014 & 17 & 0.34 \\
\hline 12 & 5025 & 5 & 0.10 \\
\hline 13 & 5000 & 11 & 0.22 \\
\hline 14 & 5005 & 10 & 0.20 \\
\hline 15 & 5000 & 22 & 0.44 \\
\hline 16 & 5000 & 32 & 0.64 \\
\hline 17 & 4312 & 17 & 0.39 \\
\hline 18 & 5000 & 16 & 0.32 \\
\hline 19 & 5200 & 26 & 0.50 \\
\hline 20 & 5100 & 40 & 0.78 \\
\hline 21 & 5024 & 35 & 0.70 \\
\hline Total & 104811 & 469 & $0.446 \pm 0.375$ \\
\hline
\end{tabular}


の大きさは，帽針頭大で比較的広基性の乳頭状腫汮で あり，光顕的には上皮性細胞からなり異型性は軽度であ るが，クロマチンに富み濃染した大小不同の核を有する 移行上皮癌で, 一部は扁平上皮化成の像を示している。 labeling index 計算のための計測細胞数104,811 に対す る標識細胞数は Tab. 3 に示すごとく469個であり, この 群の labeling index は0.446士0.375であつた。

（口）第 2 群; 実験飼育期間 60 週を経て生存したマウ 不数は当初30匹中16匹で, 本群には膀胱腫瘍の発生は見 られなかつた. labeling index 計算のための計測細胞数 78,923に対する標識細胞数は Tab. 4 に示すごとく 132 個 であり,この群の labeling index は0.176士0.106であ つた。

（公）第 3 群；実験飼育期間60週を経て屠殺した 9 匹 のマウスについて調査した結果, 膀胱腫瘍の発生はみら れず labeling index 計算のための 計測細胞数 43,669 に 対する標識細胞数は56個で, Tab. 5 に示すごとく本群の labeling index は0.127士0.047であつた。

（二）第 4 群；対照群で60週を経て屠殺したマウス数 は12匹中11匹であつた. 本群には膀胱腫瘍発生はみられ ず, labeling index 計算のための計測細胞数 56,448 に対

Tab. 4. Labeling of Bladder Epithelium by ${ }^{3} \mathrm{H}-$ Thymidine (Group-2)

\begin{tabular}{c|c|c|c}
\hline $\begin{array}{c}\text { Mouse } \\
\text { No. }\end{array}$ & $\begin{array}{c}\text { No. of cells } \\
\text { counted }\end{array}$ & $\begin{array}{l}\text { No. of } \\
\text { labeled cells }\end{array}$ & $\begin{array}{c}\text { Labeling index } \\
(\%)\end{array}$ \\
\hline 1 & 5000 & 12 & 0.24 \\
\hline 2 & 5000 & 7 & 0.14 \\
\hline 3 & 5290 & 12 & 0.23 \\
\hline 4 & 5113 & 8 & 0.16 \\
\hline 5 & 5003 & 6 & 0.12 \\
\hline 6 & 5160 & 8 & 0.16 \\
\hline 7 & 3883 & 5 & 0.13 \\
\hline 8 & 5000 & 10 & 0.20 \\
\hline 9 & 5000 & 4 & 0.08 \\
\hline 10 & 5000 & 7 & 0.16 \\
\hline 11 & 4374 & 7 & 0.29 \\
\hline 12 & 5000 & 3 & 0.06 \\
\hline 13 & 5100 & 26 & 0.51 \\
\hline 14 & 5000 & 3 & 0.06 \\
\hline 15 & 5000 & 9 & 0.18 \\
\hline 16 & 5000 & 5 & 0.10 \\
\hline Total & 78923 & 132 & $0.176 \pm 0.106$ \\
\hline & & & \\
\hline
\end{tabular}

Tab. 5. Labeling of Bladder Epithelium by ${ }^{3} \mathrm{H}-$ Thymidine (Group-3)

\begin{tabular}{c|c|c|c}
\hline $\begin{array}{c}\text { Mouse } \\
\text { No. }\end{array}$ & $\begin{array}{c}\text { No. of cells } \\
\text { counted }\end{array}$ & $\begin{array}{c}\text { No. of } \\
\text { labeled cells }\end{array}$ & $\begin{array}{c}\text { Labeling index } \\
(\%)\end{array}$ \\
\hline 1 & 5000 & 2 & 0.04 \\
\hline 2 & 4000 & 4 & 0.10 \\
\hline 3 & 4959 & 9 & 0.18 \\
\hline 4 & 4633 & 8 & 0.17 \\
\hline 5 & 5000 & 7 & 0.14 \\
\hline 6 & 5100 & 5 & 0.10 \\
\hline 7 & 5002 & 9 & 0.18 \\
\hline 8 & 5025 & 8 & 0.16 \\
\hline 9 & 4950 & 4 & 0.08 \\
\hline Total & 43669 & 56 & $0.127 \pm 0.047$ \\
\hline
\end{tabular}

Tab. 6. Labeling of Bladder Epithelium by ${ }^{3} \mathrm{H}-$ Thymidine (Group-4)

\begin{tabular}{c|c|c|c}
\hline $\begin{array}{c}\text { Mouse } \\
\text { No. }\end{array}$ & $\begin{array}{c}\text { No. of cells } \\
\text { counted }\end{array}$ & $\begin{array}{c}\text { No. of } \\
\text { labeled cells }\end{array}$ & $\begin{array}{c}\text { Labeling index } \\
(\%)\end{array}$ \\
\hline 1 & 5162 & 1 & 0.02 \\
\hline 2 & 5000 & 3 & 0.06 \\
\hline 3 & 5018 & 3 & 0.06 \\
\hline 4 & 5933 & 3 & 0.05 \\
\hline 5 & 5214 & 3 & 0.06 \\
\hline 6 & 5021 & 2 & 0.04 \\
\hline 7 & 5000 & 1 & 0.02 \\
\hline 8 & 5000 & 5 & 0.10 \\
\hline 9 & 5100 & 3 & 0.06 \\
\hline 10 & 5000 & 2 & 0.04 \\
\hline 11 & 5000 & 0 & 0.00 \\
\hline Total & 56448 & 25 & $0.04 \pm 0.025$ \\
\hline
\end{tabular}

する標識細胞数は Tab. 6 に示すごとく25個であり，こ の群の labeling index は0.04士0.025であつた.

（4）各実験群相互間の膀胱粘膜 labeling index $の$ 対比

各実験群の labeling index 計算結果を総括して Tab. 7 に示す. 各群と対照群間で! 検定を行つてみると、第 1 群は対照群に対し $\mathrm{t}=3.338, \mathrm{p}<0.01$ で有意差を示 ᄂ, 第 2 群は対照群に対し, $\mathrm{t}=3.79, \mathrm{p}<0.01$ で有意差 を示し, 第 3 群は対照群に対し, $\mathrm{t}=4.80, \mathrm{p}<0.01$ で有 意差を示した。 また第 1 群は第 2 群に対して $\mathrm{t}=2.78$, $\mathrm{p}<0.05$ で有意差を示した。 
Tab. 7. ${ }^{3} \mathrm{H}$-thymidine uptake of bladder mucosa and incidence of vesical tumor in each groups

\begin{tabular}{c|c|c|c|c|c|c}
\hline Groups & $\begin{array}{c}\text { No. of } \\
\text { Mice }\end{array}$ & $\begin{array}{l}\text { No. of cells } \\
\text { counted }\end{array}$ & $\begin{array}{l}\text { No. of } \\
\text { labeled cells }\end{array}$ & $\begin{array}{c}\text { Labeling index } \\
(\%)\end{array}$ & $\begin{array}{l}\text { Hyperplastic } \\
\text { Index }\end{array}$ & $\begin{array}{l}\text { No. of } \\
\text { Tumors (\%) }\end{array}$ \\
\hline 1 & 21 & 104,811 & 469 & $0.446 \pm 0.376$ & 43 & $2(9.5)$ \\
\hline 2 & 16 & 78,923 & 132 & $0.176 \pm 0.100$ & 32 & 0 \\
\hline 3 & 9 & 33,669 & 56 & $0.127 \pm 0.047$ & 7 & 0 \\
\hline 4 & 11 & 56,448 & 25 & $0.046 \pm 0.025$ & 0 & 0 \\
\hline
\end{tabular}

（5） 各実験群相互間の膀胱粘膜 hyperplastic index の対比 (Tab. 7)

膀胱の Hematoxylin-Eosin 染色標本で Tab. 1 に倣い HPI を計算してみると, 第 1 群は 43 , 第 2 群は 32 , 第 3 群は 7 ，第 4 群は 0 であつた。すなわち第 1 群と第 2 群は indecisive の範疇に入るが, 第 1 群は chemical induced に近い値を示し, 第 2 群は inactive に近い值 を示した. 第 3 群と第 4 群は inactive であつた。

\section{考按}

職業性膀胱癌患者の発癌潜伏期間は報告者間の多少の 差がみられるが平均18年の長期にわたつている1213) 3) 5)6) 7) 8) 9) 10). (Tab. 8). これらの患者は初発因子として benzidine や2-naphthylamine などの暴露を受け引き長期間 一職場に従事した者もあるが, 一定期間の暴露後は, 全 く発癌物質に暴露されない者もある. 後者に掞いて問題 となり興味あることは, 初発因子としての発癌物質被暴 後長期を経て発癌に到る過程には, 他になにか癌化を促 進する因子が存在するであろらことが想像され，その 1 因子として，try. 代謝異常による 尿中 try. 代謝産物の 増加が考えられてきた。

Tab. 8. Latent Period of Aromatic Amine Cancers

\begin{tabular}{l|c|c}
\hline \multicolumn{1}{c|}{ Author } & Range (years) & $\begin{array}{c}\text { Mean Value } \\
\text { (years) }\end{array}$ \\
\hline Rehn (1895) & $15 \sim 29$ & 21 \\
\hline Oppenheimer (1927) & $1 \sim 45$ & 18 \\
\hline Müller (1936) & $2 \sim 28$ & 18 \\
\hline Goldblatt (1947) & $4 \sim 48$ & 19 \\
\hline Scott (1952) & $4 \sim 33$ & 16 \\
\hline Case et al (1954) & $2 \sim 45$ & 18 \\
\hline Scott (1959) & $4 \sim 41$ & 20 \\
\hline Tsuji (1962) & $4 \sim 23$ & 9.2 \\
\hline Iki (1970) & $3.8 \sim 26.9$ & 12.4 \\
\hline Ishizu (1973) & $1 \sim 45$ & 16.5 \\
\hline Our cases (1974) & $8 \sim 28$ & 15.5 \\
\hline
\end{tabular}

自然発生膀胱癌の発癌に尿中 try. 代謝産物が関与し ているか否かを証明する手段として try. 代謝産物が膀 脱発癌を示すか否かを動物実験的に実証することは意味 がある。

Rauschenbach $^{13)}$ (1963) は, 経口的, 皮下注射法およ び経腹膜的に try.とその代謝産物を動物に投与したが， 膀胱発癌はみられなかつたと報告している. Bryan ${ }^{14)}$ （1968）は xanthurenic acid 8-methyl ether を44週マウ スに皮下注射してその膀胼発癌実験を試みたが，膀胱発 癌はみられずリンパ系悪性腫瘍の発生をみた。また同年 彼は, 3-hydroxy anthranilic acid をマウスに経口投与し て同様の実験を行つたが，膀胱癌の発生はみられず白血 病とリンパ系悪性腫瘍を認めた。 以上の実験結果にみる ごとく try. 怙よびその代謝産物の全身投与法による膀 胱発癌実験の失敗は, try. およびその代謝産物が肝に おいて代謝され非芳香族化合物になるためと考学られ $た^{15)}$.

非経口的膀胱発癌実験では Jull ${ }^{16)}$ (1951), Allenら ${ }^{17)}$ （1957）の pellet implantation 法による実験が歴史的 に有名であり 1 実験方法となつた．との方法は発癌実 験化合物をコレステロールかパラフィンを基剤として混 合し, pellet を作り，直接マウス膀脱内に挿入する方 法である. Allen ら ${ }^{17)}$ (1957), Bryan ら ${ }^{18)}$ (1964) は pellet implantation 法により xanthurenic acid 8-methylether, 3-hydroxy kynurenine, xanthurenic acid, 3-hydroxy anthranilic acidd $と 3$-hydroxy-2 aminoacetophenon の 5 種類の try. 代謝産物を用い膀胱発癌実験に成功し た.しかし,この方法は, pellet 自体の癌化に対する影 響の存在が論議されるようになつた. Bryan ら ${ }^{19)}$ (1964) は pellet 内の発癌実験化合物は 6 日以内の短期間に pellet より溶出する事実を見出した。 それ故, Bryan \& Springberg $^{15)}$ (1966) は, 膀脱に発癌する機序は, 実験 化合物が初発因子として作用し pellet は長期膀胱内に 残留し促進因子として作用するためと考えた．以上のよ らな諸研究者による膀胱発癌実験成績から, Bryan \& 
Morris $^{20)}$ (1968) はコレステロール pelletをマウス膀 脱内に挿入して xanthurenic acid 8-methyl ether 44 週, 皮下注射することによつて膀胱の発癌に成功した。 このような諸事実から Bryan $^{21)}$ (1969）は人間において も，実験動物之同椂に膀胱の発癌に沶いて，初発因子と 促進因子の存在を想定した。

Rodamski ら 22) (1971) は 4 年間以上にわたつて犬に dl-try. を経口的に摂取させたところ膀胱粘膜に発癌はみ られなかつたが, hyperplasia が生ずることを立証し， 4-aminodiphenyl を 1 回経口投与し，その後 dl-try. を引 続いて投与寸る方法で膀脱癌の発生を認めている。この 実験は dl-try. の経口投与法による try. の促進因子的役 割を立証した実験として意義がある。

Ertürk ら ${ }^{11)}$ (1967) は第10回国際ガン学会で種族差 がなく, 膀脱に対して臟器特異的に注ぼ 100\%発癌性を 有する nitrofuran 化合物である N-[4-(5-nitro-2-furyl)2thiazolyl] formamide (FANFT) について発表した。

今回，著者は try. の膀脱発癌に括ける促進的役割を より明確に立証すべくマウスを使用し，初発因子として FANFTを投与し，促進因子として通常生体内で代謝さ れる try. 添加食飼で飼育する実験を試みた。その結果, 1-try. 添加食飼育群（第 1 群）に批いて，2 例の膀脱発 癌に成功し， ${ }^{3} \mathrm{H}$-thymidine による autoradiography を用 い膀胼粘膜の labeling index と hyperplastic index を観 察したが，そのいずれの值も対照群に比し有意の差をむ つて高值であることを立証した。しかし初発因子のみで 促進因子の付与されない第 2 群には発癌をみず，初発因 子のない促進因子のみの第 3 群には当然ながら発癌しな かつた，以上の実験結果から，発癌に至る過程には，初 発因子と促進因子併存の必要性が明らかとなつた。

\section{結 語}

今回，著者は膀胼発癌過程に括ける 1-try. の促進因子 的役割を検討すべく小動物発癌実験モデルを計画した。 種族差がなく臓器特異的に膀脱に発癌する FANFTを D-D 系雌マウスに短期間（4週）経口摂取させた後, l-try. を長期間 (56週) 経口㩒取させたところ次の結果 を得た。

1). 第 1 群 (FANFT 添加 CE- 2 粉未飼料で 4 週飼育 後, 1-try. 添加 CE-2 固型飼料 で 56 週飼育群), 第 2 群 (FANFT 添加 CE-2粉末飼料で 4 週飼育後, CE-2 固型 飼料で56週飼育群) および第 3 群 (1-try. 添加 CE-2 固 型飼料で60週飼育群) は共に対照群である第 4 群 (CE2固型飼料飼育群) に対して, 膀胱粘膜の labeling index
計算結果から $\mathrm{t}$ 検定で有意差を示した。

2）第 1 群と第 2 群の実験結果を比較すると, 第 1 群では明らかに 2 例の膀胱腫瘍の発生を認め, labeling index 打よび hyperplastic index に抒いても, 第 1 群は 第 2 群に対して有意差を示した．以上の事実は 1-try が マウス膀胱発癌になんらかの促進因子的役割を果してい るものと考えられる。

本論文の要旨は, 第63回日本泌尿器科学会総会におい て発表した。

稿を終るにあたり，ご指導，ご校閲を賜わつた恩師安 藤弘教授に深甚な謝意を表します。さらにFANFTを提 供して下さいょした京都大学吉田修教授に深謝いたしま す.

\section{文献}

1) Rehn, L.: Arch. Klin. Chir., 50, 588, 1895.

2) Oppenheimer, R.: Z. Urol. Chir., 21, 336, 1927.

3) Müller, A.: Schweiz. Med. Wchnschr., 66, 1031, 1936.

4) Goldblatt, M.W.: Brit. Med. Bull., 4, 405, 1947.

5) Scott, T.S.: Brit. J. Indust. Med., 9, 127, 1952.

6) Case, R.A.M. and Hosker, M.E.: Brit. J. Prev. Soc. Med., 8, 39, 1954.

7) Scott, T.S.: Trans. Ass. Indust. Med. off., 9, 57, 1959.

8) Tsuji, I.: Acta Unio, 18, 662, 1962.

9) 志岐太一郎 : 久留米医学雑誌, 33，363，1970.

10) 石津澄子：東女医大誌， 43，339，1973.

11) Ertürk, E., Price, J.M., Morris, J.E., Cohen, S., Leith, R.S., Von Esch, A.M. and Crovetti, A. J.: Cancer Res., 27, 1998, 1967.

12）宮川美栄子：泌尿紀要，16，653，1970。

13) Rauschenbach, M.O., Jarova, E.I. and Protosova, T.G.: Acta Unio. Intern Contra Cancrum, 19, 660, 1963.

14) Bryan, G.T.: Cancer Res., 28, 183, 1968.

15) Bryan, G.T. and Springberg, P.D.: Cancer Res., 26, 105, 1966.

16) Jull, J.W.: Brit. J. Cancer, 5, 388, 1951.

17) Allen, M.J., Boyland, E., Dukes, C.E., Horning, E.S. and Watson, J.G.: Brit. J. Cancer, 11, $212,1957$.

18) Bryan, G.T., Brown, R.R. and Price, J. M.: Cancer Res., 24, 596, 1964.

19) Bryan, G.T., Brown, R.R., Morris, C.R. and Price, J.M.: Cancer Res., 24, 586, 1964.

20) Bryan, G.T. and Morris, P.D.: Cancer Res., 28, 186, 1968.

21) Bryan, G.T.: Am. Indust. Hyg. Ass. J., 30, 27, 1969.

22) Rodamski, J.L., Glass, E.M. and Deichmann, W.B.: Cancer Res., 31, 1690, 1971.

（1977年 4 月 1 日受付，特別掲载） 